\title{
Morphometric and meristic characters of Otolithoides pama (Hamilton,1822) occurring in Hooghly-Matlah estuarine system of West Bengal, India
}

\author{
DIBAKAR BHAKTA*, SUDHIR KUMAR DAS, BASANTA KUMAR DAS* AND T. S. NAGESH \\ Department of Fisheries Resource Management, Faculty of Fishery Sciences, West Bengal Univerisity of Animal \\ and Fishery Sciences, Chakgaria, Kolkata - 700 094, West Bengal, India \\ *ICAR-Central Inland Fisheries Research Institute, Barrackpore, Monirampore, Kolkata - 700 120, West Bengal, India \\ e-mail:dibakar.bhakta@icar.gov.in
}

\begin{abstract}
The present study analysed the morphometric and meristic characters of Otolithoides pama (Hamilton, 1822) collected from the Hooghly-Matlah estuarine system of West Bengal, India. A total of 618 specimens (298 males and 320 females) were collected during the period of 18 months from November 2016 to April 2018 with length ranging from 100-384 mm and weight 7.29-470.71 g, respectively. The analysis of 14 morphometric characters revealed that standard length has the fastest growth rate when compared to total length, while eye diameter has the lowest growth rate compared with head length. A high degree of significant positive correlation with the ' $r$ ' values ranging from 0.978 to 0.997 was observed among different morphometric characters of $O$. pama. Among nine of the meristic counts, the coefficient of variation was found to be highest in anal fin rays $(6.31 \%)$ and minimum in dorsal fin rays $(1.12 \%)$. Based on the meristic counts, the fin formula of $O$. pama from the present study can be described as B. ${ }_{7}$, D. 9-10/1/ ${ }_{44-45}$, P. i/ ${ }_{16-17}$, V. $1 /{ }_{5}$, A. $2 /{ }_{7-8}$, C. ${ }_{19-21}$, L. 48-52. The number of gill rakers on the first left gill arch ranged from 19-21.
\end{abstract}

Keywords: Hooghly-Matlah Estuary, Meristic counts, Morphometric characters, Otolithoides pama, West Bengal

\section{Introduction}

Morphological characters, such as body shape and meristic counts, have long been used to delineate fish stocks (Heincke, 1898; Teugels, 1982; Villaluz and Maccrimmon, 1988; Haddon and Willis, 1995; Silva, 2003; Turan, 2004). It includes the analysis of body shape or the shape of particular morphological features of various dimensions or parts and provides adequate information for identifying marine fish stocks and describing their spatial distributions (Ihssen et al., 1981). Morphometric data are continuous (e.g. head length and body length) while meristic characters are enumerable morphological features (e.g. fin rays, gill rakers and scales in rows) of fishes. An important aspect of the meristic analysis is that data obtained are discrete. Data on morphometric measurements can identify differences between fish populations and used to describe the shape of fish. They are measurable features that are helpful to separate closely related genera, species and even populations within (Cadrin, 2000).

Statistical analysis of morphometric characters gives a better idea of relationships within species and also to compare with the same species in different geographical areas. The taxonomic classification of organisms and understanding the diversity of biological life, were historically based on descriptions of morphological forms (Dean et al., 2003). Morphological characters have been commonly used in fisheries biology to measure discreteness and relationships among various taxonomic categories (Quilang et al., 2007).

Several works on morphometric and meristic parameters have been done on sciaenids in the Indian context. Some of the studies are by Rao (1963) on Pseudosciaena (=Protonibea) diacanthus, Jayaprakash (1974) on Johnieops sina (=Johnius dussumieri). Basu (1975) on Otolithes argenteus, Gandhi (1982) on Pennahia anea from Porto Novo waters, Jayasankar (1989) on Nibea maculata from Mandapam waters, Manojkumar and Acharya (1990) on Otolithoides biauritus from Bombay waters, Chakraborty (1992) on Otolithes cuvieri, Johnius macrorhynus and Johnius vogleri (=borneensis) from Bombay waters, Bhuyan (2003) on Johnius carutta, Pennahia macrophthalmus (=anea) and Otolithes ruber from Odisha coast, Manojkumar (2011) on J. sina and O. cuvieri along the Malabar coast and off Veraval, Kumar (2012) on J. sina and Sandhya (2015) on O. cuvieri.

Sciaenid fishes are represented by 49 species, belonging to 22 genera in the Indian Ocean of which 40 species belonging to 20 genera, inhabit the seas of India (Talwar, 1995). Two large-size species viz., Macrospinosa 
cuja (Hamilton-Buchanan) and Daysciaena albida (Cuvier) contribute to significant fisheries in Indian estuarine waters, while two fairly small species, Pama (=Otolithoides) pama (Hamilton-Buchanan) and Johnius gangeticus form a fishery in Ganga River (Talwar, 1995; Bhakta et al., 2020). Otolithoides pama (Hamilton, 1822) is the third most abundant fish species after hilsa (Tenualosa ilisha) and Bombayduck (Harpodon nehereus) from Hooghly-Matlah estuarine system, West Bengal (Kumar etal., 2012).O.pama earlier known as P.pama (Sciaenoides pama) locally called as 'Bhola' or 'Poa Bhola' or 'Coi-bola' or 'Jat Bhola' forms an important fishery in Hooghly-Matlah estuarine system (Bhakta et al., 2009a; b). No reports on details of morphometric relationships of O. pama from the Hooghly-Matlah estuarine system is available till now. So, an attempt was made to estimate the morphometric relationship of $O$. pama occurring in the Hooghly-Matlah estuarine system of West Bengal, India.

\section{Materials and methods}

The present study is based on 618 specimens of O. pama in the length range of $107-384 \mathrm{~mm}(195.65 \pm 38.35 \mathrm{~mm})$ and weight range from 10.20 to $470.71 \mathrm{~g}(65.57 \pm 47.55 \mathrm{~g})$ collected from three selected landing sites such as Godakhali, Diamond Harbour and Frasergang of HooghlyMatlah estuarine system of West Bengal during November 2016 to April 2018. Fresh specimens were utilised for the study of morphometric and meristic characters. The total length of all individuals was measured from the tip of the snout to the tail to the nearest $0.1 \mathrm{~mm}$ and weight was taken using an electronic balance (to an accuracy of $0.01 \mathrm{~g}$ ). A total of fourteen morphometric and nine meristic characters were studied (Fig. 1) following the standard procedure adopted by Lowe-McConnel (1971), Dwivedi and Menezes (1974); Grant and Spain (1977). For the analysis of morphometric characters, scatter diagrams were plotted and then the linear regression equation was fitted using the least square method described by Laevestu (1965) and Snedecor and Cochran (1967).

Meristic characters included the number of spines and rays on pectoral, dorsal, anal, pelvic and caudal fins. The first gill arch was taken from the left operculum for the count of gill rakers. The characters were counted using a magnifying lens and needle to separate the rays. Relationships between various body measurements to the total length and head length have been calculated. Range, mean, standard deviations, standard errors and coefficient of variation were also calculated for characters under study.

\section{Results and discussion}

The morphometric study was carried out on 618 specimens of $O$. pama with size ranging from 100 to $384 \mathrm{~mm}$ total length. The calculated descriptive statistics like the range, mean, standard deviation, standard error and coefficient of variation of various morphometric

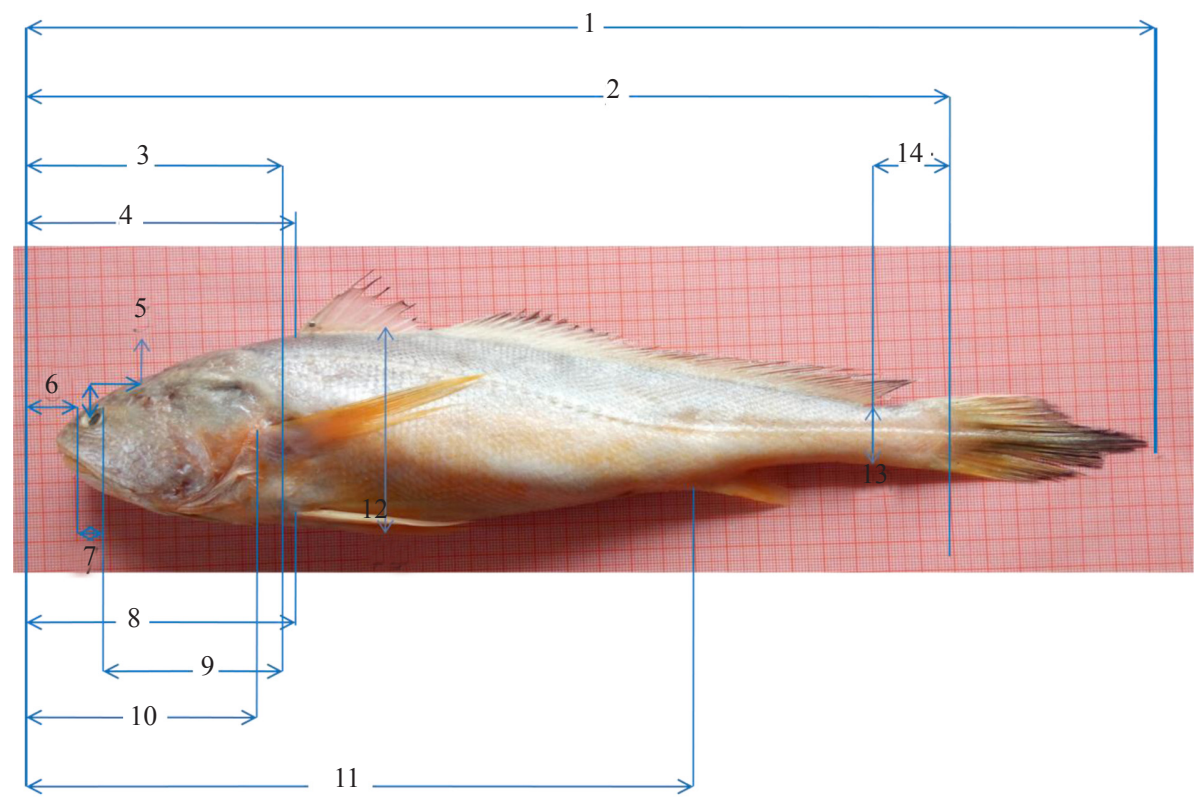

Fig. 1. Morphometric characters of $O$. pama. 1. Total length (TL), 2. Standard length (SL), 3. Head length (HL), 4. Pre-dorsal length (PDL), 5. Inter-orbital length (IOL), 6. Snout length (SNL), 7. Eye diameter (ED), 8. Pre-pelvic length (PPL), 9. Post-orbital length (POL), 10. Pre-pectoral length (PPeL), 11. Pre-anal length (PAL), 12. Body depth (BD), 13. Caudal depth (CD), 14. Caudal peduncle length (CPL) 
characters are presented in Table 1. The results indicated maximum coefficient of variations in caudal depth $(22.63 \%)$ followed by post-orbital length (22.30\%), pre-dorsal length $(20.60 \%)$ and pre-pectoral length (19.96\%).

The values of ' $b$ ' indicated the highest growth rate for standard length (0.834), followed by pre-anal length (0.627), pre-dorsal length (0.247) and lowest for caudal length (0.080) when compared with total length (Table 2). Similarly, when morphometric characters were compared against head length, the highest growth rate (b) was observed for pre-orbital length (0.808), followed by inter-orbital length (0.284) and the minimum with eye diameter $(0.128)$. The growth rate (b) observed was 0.356 when caudal depth was compared with body depth.

The coefficient of correlation between different characters ranged from 0.978 to 0.997 (Table 2). Standard length showed a maximum degree of correlation (0.997) with total length, while caudal length showed the minimum
(0.978). Correlation coefficient of head length with other morphometric characters was found minimum with eye diameter (0.939) and maximum with caudal depth as well as inter-orbital length (0.973).

A high degree of significant positive correlation among different morphometric characters of $O$. pama was observed in the present study. The regression coefficient ' $b$ ' indicated a high degree of homogeneity within the population. Among various characters studied, total length, standard length and pre-anal length showed very high degree of positive correlation. But, body depth in relation to per unit change of total length and caudal depth in relation to per unit change in body depth showed slowest growth rate of the species compared to other morphometric characters (Fig. 2a-j).

According to Basu (1975), there was a high degree of correlation between total length and standard length of Otolithes argentius from Mumbai waters. A similar kind

Table 1. Statistical estimates of various morphometric characters of $O$. pama

\begin{tabular}{|c|c|c|c|c|c|c|}
\hline \multirow{2}{*}{ Morphometric characters } & \multicolumn{2}{|c|}{ Range (mm) } & \multirow{2}{*}{ Mean (mm) } & \multirow{2}{*}{ Standard Deviation } & \multirow{2}{*}{ Standard Error } & \multirow{2}{*}{ Coefficient of Variation (\%) } \\
\hline & Min. & Max. & & & & \\
\hline Total length & 100.00 & 384.00 & 192.65 & 33.61 & 1.35 & 17.45 \\
\hline Standard length & 72.00 & 312.00 & 150.75 & 28.10 & 1.13 & 18.64 \\
\hline Pre-anal length & 58.00 & 237.00 & 109.12 & 21.19 & 0.85 & 19.42 \\
\hline Pre-dorsal length & 19.00 & 85.00 & 40.72 & 0.21 & 0.34 & 20.60 \\
\hline Pre-pelvic length & 22.00 & 90.00 & 41.83 & 8.12 & 0.33 & 19.42 \\
\hline Pre-pectoral length & 17.00 & 81.00 & 39.70 & 7.92 & 0.32 & 19.96 \\
\hline Head length & 21.00 & 85.00 & 41.57 & 7.81 & 0.31 & 18.78 \\
\hline Body depth & 17.00 & 90.00 & 39.04 & 7.56 & 0.30 & 19.37 \\
\hline Caudal depth & 5.00 & 29.00 & 12.07 & 2.73 & 0.11 & 22.63 \\
\hline Caudal length & 21.00 & 77.00 & 43.13 & 7.31 & 0.29 & 16.95 \\
\hline Snout length & 4.50 & 24.00 & 10.06 & 1.97 & 0.08 & 19.58 \\
\hline Post-orbital length & 7.00 & 62.00 & 28.94 & 6.45 & 0.26 & 22.30 \\
\hline Inter-orbital length & 7.50 & 27.00 & 13.78 & 2.25 & 0.09 & 16.31 \\
\hline Eye diameter & 3.00 & 11.00 & 6.43 & 1.04 & 0.04 & 16.15 \\
\hline
\end{tabular}

Table 2. Relationship between different morphometric characters of $O$. pama

\begin{tabular}{lll}
\hline Morphometric characters & $\mathrm{Y}=\mathrm{a}+\mathrm{bx}$ & ' $\mathrm{r}$ ' value \\
\hline Standard length and Total length & $\mathrm{Y}=-10.07+0.834$ & 0.997 \\
Pre-anal length and Total length & $\mathrm{Y}=-11.81+0.627$ & 0.990 \\
Pre-dorsal length and Total length & $\mathrm{Y}=-6.967+0.247$ & 0.983 \\
Pre-pelvic length and Total length & $\mathrm{Y}=-4.450+0.240$ & 0.987 \\
Pre-pectoral length and Total length & $\mathrm{Y}=-5.389+0.234$ & 0.986 \\
Head length and Total length & $\mathrm{Y}=-2.910+0.230$ & 0.988 \\
Body depth and Total length & $\mathrm{Y}=-4.004+0.223$ & 0.988 \\
Caudal length and Total length & $\mathrm{Y}=1.525+0.216$ & 0.986 \\
Caudal depth and Total length & $\mathrm{Y}=-.3 .415+0.080$ & 0.978 \\
Post-orbital length and Head length & $\mathrm{Y}=-4.649+0.808$ & 0.962 \\
Inter-orbital length and Head length & $\mathrm{Y}=1.977+0.284$ & 0.973 \\
Snout length and Head length & $\mathrm{Y}=-0.263+0.248$ & 0.968 \\
Eye diameter and Head length & $\mathrm{Y}=1.075+0.128$ & 0.939 \\
Caudal depth and Body depth & $\mathrm{Y}=-1.842+0.356$ & 0.973
\end{tabular}




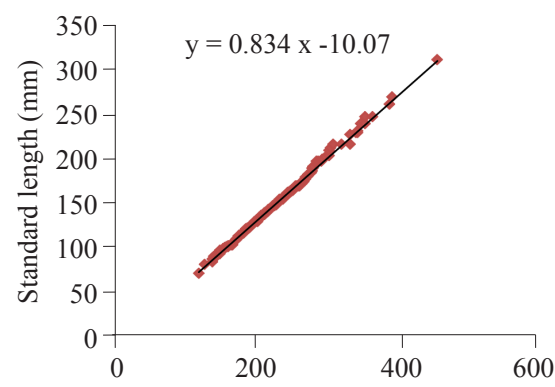

(a)

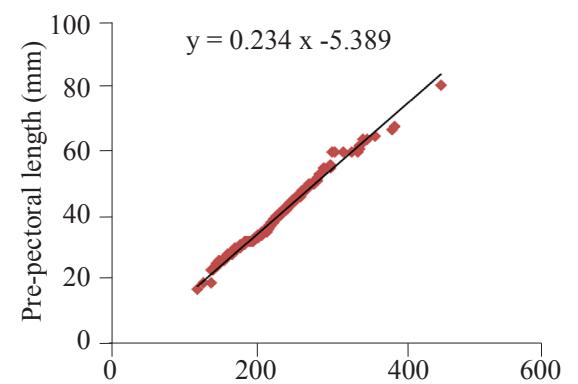

(d)

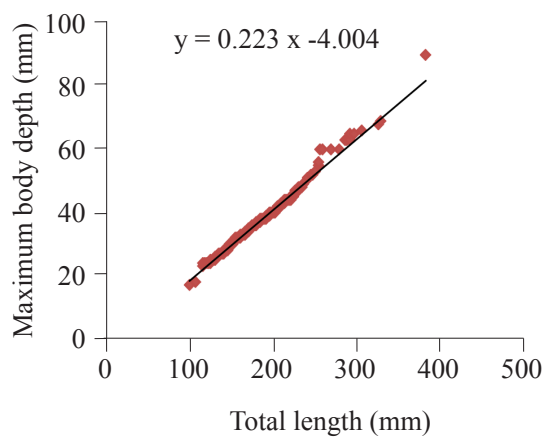

(g)

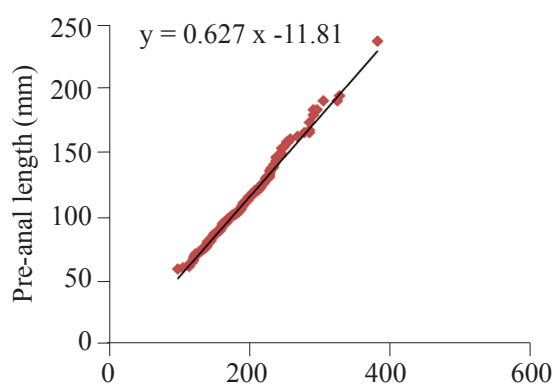

(b)

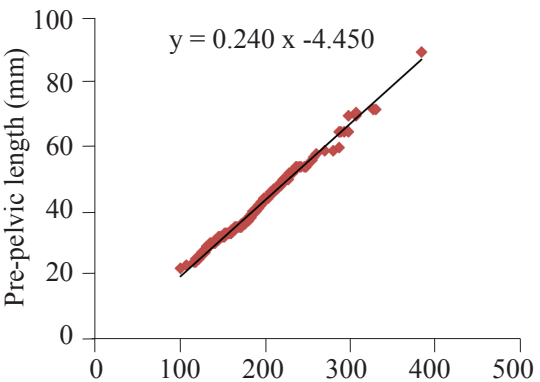

(e)

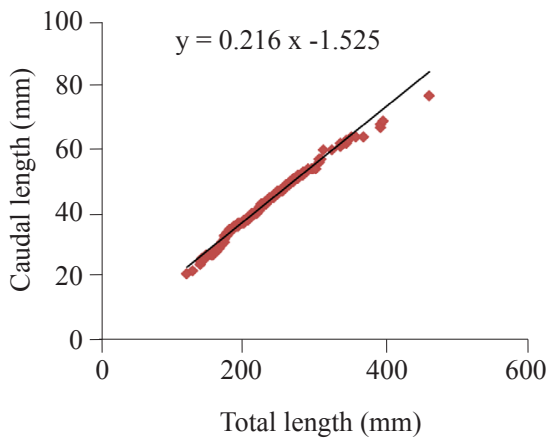

(h)

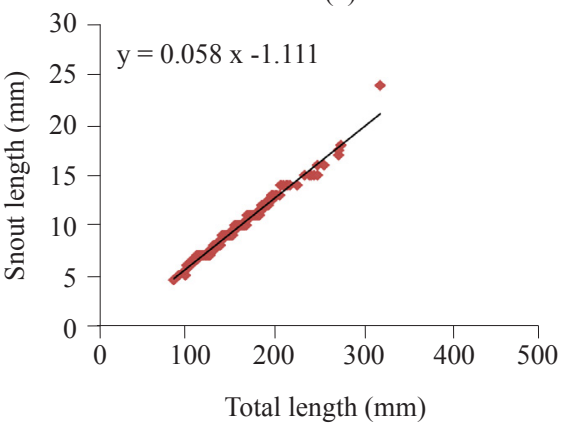

(j)

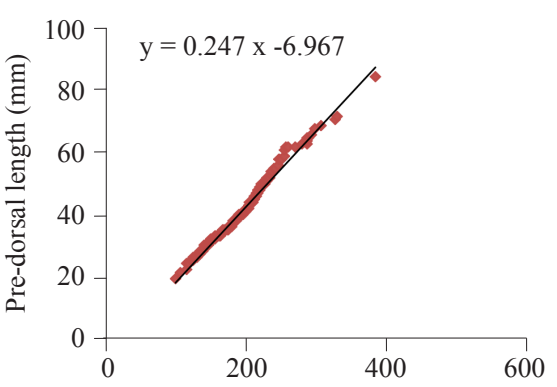

(c)

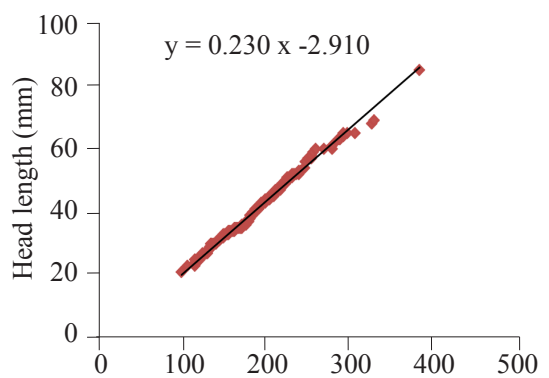

(f)

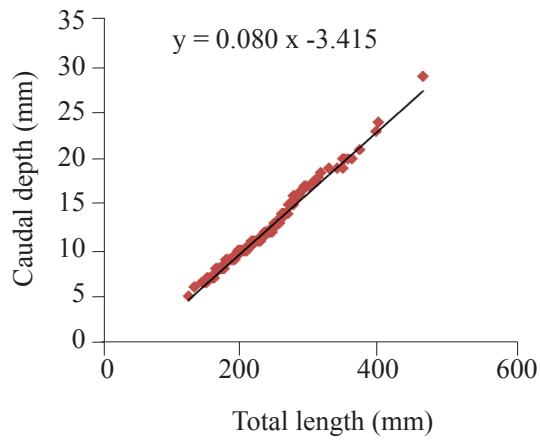

(i)

Fig. 2. Scatter diagram showing different morphometric characters against the total length of $O$. pama

of result was also reported by Chakraborty (1992) in his studies and mentioned a high degree of correlation between standard length and the total length of Otolithes cuvieri from Mumbai waters. Body parts of the respective species grow with increase in total length and have been reported by Dobriyal et al. (2006). Growth rates in other parts like pre-pelvic length, head length, pre-pectoral length, caudal length and pre-dorsal length in relation to per unit change in total length, as well as post-orbital length, snout length and inter-orbital length in relation to per unit change in head length, were faster than other compared characters for the species (Fig. 3a-d). 


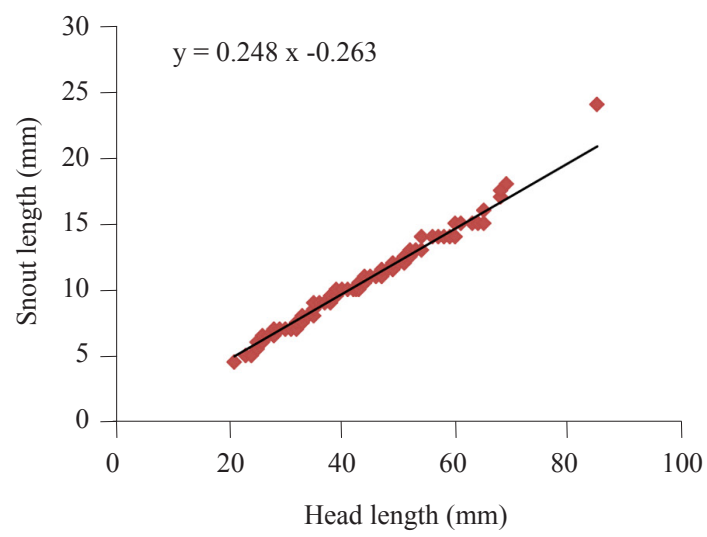

(a)

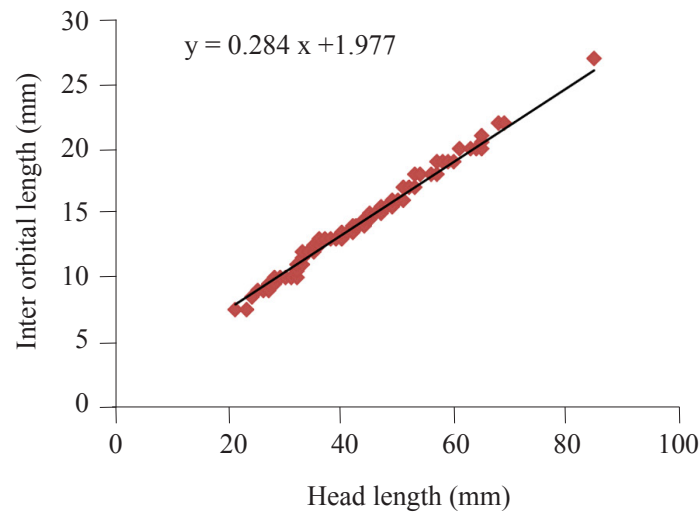

(c)

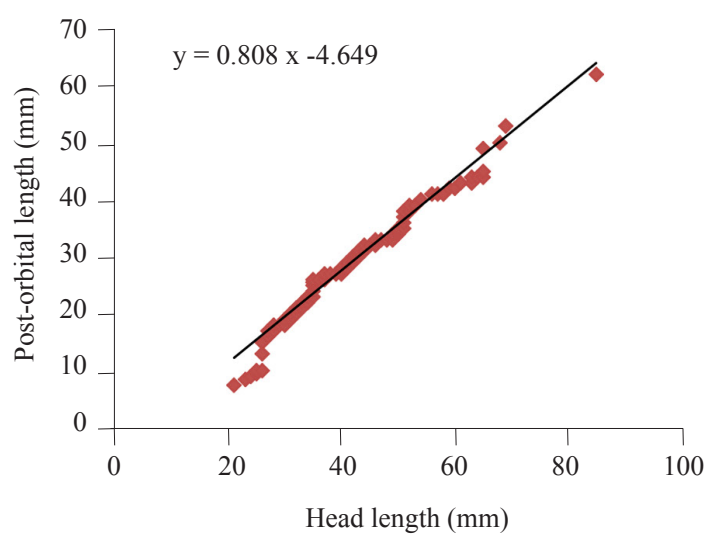

(b)

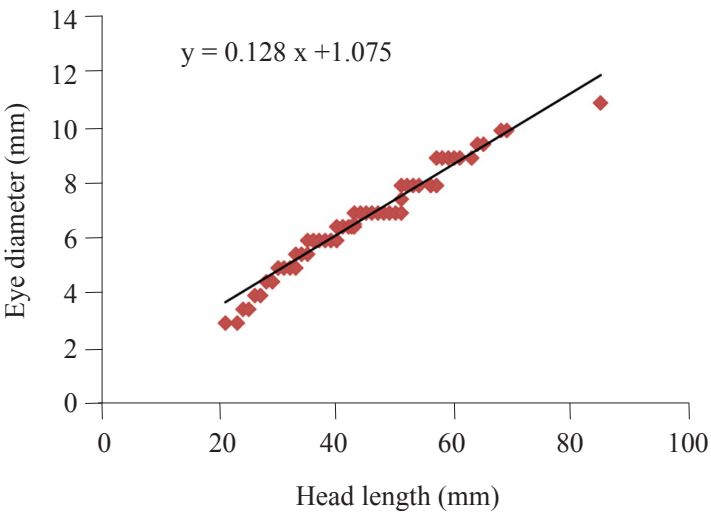

(d)

Fig. 3. Scatter diagram showing different morphometric characters against the head length of O. pama

Several workers have reported similar kinds of growth pattern in their respective studies in Indian waters like Gandhi (1982) in Pennahia anea, Pillai (1983) in O. ruber, Manojkumar and Acharya (1990) in O. biauritus, Chakraborty (1992) in J. macrorhynus and J. vogleri, Bhuyan (2003) in O. ruber, J. carutta and Pennahia macrophthalmus and Telvekar (2006) in J. sina.

Gandhi (1982) reported that total length showed the fastest growth rate followed by pre-anal length and eye diameter has the lowest growth rate in $P$. anea from Port Novo waters. According to Pillai (1983), out of 17 morphometric characters studied, the growth rate of pre-anal fin length was found to be the fastest in $O$. ruber from the Port Novo coast. A similar kind of growth rate was also reported by Chakraborty (1988) on Otolithes cuvieri, Johnieops vogleri from Mumbai waters and J. macrorhynus and Raje (1988) on Attrobuca nibe off Veraval coast of India. Manojkumar and Acharya (1990) mentioned that anal length showed maximum $(\mathrm{r}=0.996)$ and pectoral length minimum $(\mathrm{r}=0.908)$ correlation when compared to total length while orbital width and snout length showed highest and lowest $(\mathrm{r}=0.998$ and
0.898 ) correlation respectively compared to head length in Otolitoides biauritus collected from Bombay waters. A relatively poor correlation of total length against body depth and head length for J. macrorhynus was observed by Chakraborty (1992) from Bombay waters. Bhuyan (2003) reported that pre-anal length has the fastest growth rate in relation to total length while eye diameter has the lowest growth rate in relation to head length in $O$. ruber off Paradip coast.

Telveker (2006) also reported that standard length followed by pre-anal length has the fastest growth rate in relation to total length while eye diameter has the lowest growth rate in relation to the head length of Otolithes cuvieri from Mumbai waters. Kumar (2012) mentioned that in J. sina collected from Ratnagiri waters, standard length and pre-anal length showed a very high degree of positive correlation among the various characters while caudal depth and body depth showed a low degree of positive correlation. Sandhya et al. (2015) found that standard length and pre-anal length showed the highest growth rate against total length and caudal length growth rate was very slow in $O$. cuvieri from Ratnagiri waters. 
The pre-orbital length indicated the highest growth rate and eye diameter the slowest compared with head length.

The range, mean, mode, median, standard deviation, standard error as well as coefficient of variance for various meristic characters were estimated and provided in Table 3. It has been observed that the first part of dorsal fin has 9 to 10 spines followed by a deep notch and the second part of the fin has 1 spine and 44 to 45 fin rays. Ventral fin has 1 spine followed by 5 rays and anal fin 2 spines and 7 fin rays. Pectoral fin has 1 unbranched fin ray and branched fin rays ranged from 16 to 17 ; caudal fin rays from 19-21, lateral line scales 48 to 52 and branchiostegal fin rays were 7 and did not show any variation from individual to individual. The coefficient of variation was found to be highest in anal fin rays $(6.31 \%)$ and minimum in dorsal fin rays $(1.12 \%)$.

Meristic characters of O. pama are presented in Table 3 and were compared with the available literature from earlier workers (Jayaprakash, 1974; FAO, 1983; Talwar and Kacker, 1984) and it is in agreement with most of such works (Table 4). The correlation of different morphometric values of $O$. pama is presented in Table 5 .

In the present study, the number of spines and branched dorsal fin rays $O$. pama varied from IX-X+I and 44 to 45 respectively. Bhuiyan (1964) reported $\mathrm{X}+\mathrm{I}$ spine and 40-43 fin rays, Shafi and Quddus (1982) reported X+I spine and 40-43 fin rays, FAO (1974) reported X+I spine and 40-45 fin rays, Mohan (1991) observed 40-45 fin rays, Talwar (1995) noticed IX-X+I spine and 40-45 rays, Talwar and Jhingran (2001) reported IX-X+I spine and 40-45 rays and Rahman (2005) reported $\mathrm{X}+\mathrm{I}$ spine and 40-43 fin rays. The number of pectoral fin rays observed in the present study was 16 , which was found similar to the works of Talwar (1995) and Talwar and Jhingran (2001) who found 16 number of fin rays in their respective studies. But Bhuiyan (1964) and Shafi and Quddus (1982) reported 17 numbers of pectoral fin rays. A total five pelvic fin rays were recorded in the present study which was also similar to the works of Bhuiyan (1964), Shafi and Quddus (1982), Talwar (1995), Talwar and Jhingran (1991) and Rahman (2005). The number of anal fin rays recorded were 7 which is similar to the finding of Bhuiyan (1964), Fischer and Whitehead (1974), Shafi and Quddus (1982), Talwar (1995), Talwar and Jhingran (1991) and Rahman (2005). The caudal fin numbers recorded were 18-20. The number of gill rakers in the lower limb of first-gill arch was found to be 19 to 21, while FAO (1974) reported 11-14 lower gill rakers and Mohan (1991) observed 16-21 and Talwar (1995) recorded 16-22 gill rakers in their respective studies. The total number of lateral line scales observed was of 48-52, but Talwar (1995) reported only 44-48 numbers of lateral line scales. In the present study, maximum number of meristic characters was found similar to the earlier studies with little difference in the number of gill rakers and the total number of lateral line

Table 3. Statistical estimates of various meristic characters of $O$. pama

\begin{tabular}{lllllllll}
\hline \multirow{2}{*}{ Meristic character } & \multicolumn{2}{c}{ Range $(\mathrm{mm})$} & \multirow{2}{*}{ Mean } & Mode & Median & Standard Error & Standard Deviation & Coefficient of Variation (\%) \\
\cline { 2 - 5 } & Min & Max & & & & & & 3.81 \\
Dorsal fin spine & 9 & 10 & 9.83 & 10 & 10 & 0.02 & 0.37 & 1.12 \\
Dorsal fin rays & 44 & 45 & 44.50 & 44 & 44.5 & 0.02 & 0.50 & 3.00 \\
Pectoral fin rays & 16 & 17 & 16.56 & 17 & 17 & 0.02 & 0.50 & - \\
Pelvic fin rays & 5 & 5 & 5.00 & 5 & 5 & - & - & - \\
Anal fin spine & 2 & 2 & 2.00 & 2 & 2 & - & - & 6.31 \\
Anal fin rays & 7 & 8 & 7.31 & 7 & 7 & 0.02 & 0.46 & 3.37 \\
Caudal fin rays & 19 & 21 & 20.00 & 20 & 20 & 0.03 & 0.67 & 2.50 \\
Gill rakers & 19 & 21 & 20.00 & 20 & 20 & 0.02 & 0.50 & - \\
Branchiostegal rays & 7 & 7 & 7.00 & 7 & 7 & - & - & \\
\hline
\end{tabular}

Table 4. Comparison of meristic characters of $O$. pama based on other studies

\begin{tabular}{|c|c|c|c|c|c|c|}
\hline Author(s) & Nos. of dorsal fin & Nos. of pectoral fin & Nos. of pelvic fin & Nos. of anal fin & Nos. of caudal fin & Nos. of gill rakers \\
\hline Bhuiyan (1964) & 10+I. $40-43$ & 17 & I. 5 & II. 7 & - & - \\
\hline Talwar (1975) & X.I. 40-45 & - & - & II. 7 & - & - \\
\hline Shafi and Quddus (1982) & X.I. $40-43$ & 17 & I. 5 & II. 7 & - & - \\
\hline FAO (1974) & X.I. $40-45$ & - & - & II. 7 & - & $11-14$ \\
\hline Mohan (1991) & $2^{\text {nd }}$ dorsal $40-45$ & - & - & - & - & $5-7 / 1 / 10-13$ \\
\hline Talwar (1995) & IX-X. I. 40-45 & i. 16 & I. 5 & II. $7-8$ & - & $(4-6)+1+(11-15)$ \\
\hline Talwar and Jhingran (1991) & IX-X. I. 40-45 & i. 16 & I. 5 & II. 7 & - & - \\
\hline Rahman (2005) & X.I. $40-43$ & 19 & I. & II. 7 & - & - \\
\hline Present study & IX-X.I. 44-45 & i. 16 & I. 5 & II. 7 & $19-21$ & $19-21$ \\
\hline
\end{tabular}


Table 5. Correlation of different morphometric values of O. pama

\begin{tabular}{|c|c|c|c|c|c|c|c|c|c|c|c|c|c|c|c|}
\hline \multicolumn{16}{|c|}{ Correlations } \\
\hline & $\mathrm{TL}$ & ST & PAL & PDL & PPL & PPeL & HL & MBD & $\mathrm{CD}$ & CL & SL & POL & IOL & ED & $\mathrm{CPL}$ \\
\hline TL & 1.000 & -0.031 & -0.016 & -0.015 & -0.021 & -0.022 & -0.026 & -0.014 & -0.025 & -0.023 & -0.023 & -0.023 & -0.014 & -0.027 & -0.035 \\
\hline ST & - & 1.000 & $.997^{* *}$ & $.992^{* *}$ & $.992^{* *}$ & $.992^{* *}$ & $.992^{* *}$ & $.995^{* *}$ & $.990^{* *}$ & $.991^{* *}$ & $.988^{* *}$ & $.983^{* *}$ & $.992^{* *}$ & $.976^{* *}$ & $.970^{* *}$ \\
\hline PAL & - & - & 1.000 & $.992^{* *}$ & $.990^{* *}$ & $.989^{* *}$ & $.989^{* *}$ & $.995^{* *}$ & $.989^{* *}$ & $.985^{* *}$ & $.985^{* *}$ & $.978^{* *}$ & $.991^{* *}$ & $.974^{* *}$ & $.963^{* *}$ \\
\hline PDL & - & - & - & 1.000 & $.995^{* *}$ & $.992^{* *}$ & $.993^{* *}$ & $.988^{* *}$ & $.993^{* *}$ & $.984^{* *}$ & $.980^{* *}$ & $.972^{* *}$ & $.988^{* *}$ & $.964^{* *}$ & $.961^{* *}$ \\
\hline PPL & - & - & - & - & 1.000 & $.995^{* *}$ & $.997^{* *}$ & $.985^{* *}$ & $.988^{* *}$ & $.989^{* *}$ & $.982^{* *}$ & $.979^{* *}$ & $.986^{* *}$ & $.970^{* *}$ & $.966^{* *}$ \\
\hline PPeL & - & - & - & - & - & 1.000 & $.996^{* *}$ & $.984^{* *}$ & $.988^{* *}$ & $.987^{* *}$ & $.984^{* *}$ & $.977^{* *}$ & $.983^{* *}$ & $.965^{* *}$ & $.966^{* *}$ \\
\hline HL & - & - & - & - & - & - & 1.000 & $.985^{* *}$ & $.988^{* *}$ & $.991^{* *}$ & $.984^{* *}$ & $.980^{* *}$ & $.986^{* *}$ & $.969^{* *}$ & $.971^{* *}$ \\
\hline MBD & - & - & - & - & - & - & - & 1.000 & $.987^{* *}$ & $.982^{* *}$ & $.982^{* *}$ & $.972^{* *}$ & $.990^{* *}$ & $.967^{* *}$ & $.960^{* *}$ \\
\hline $\mathrm{CD}$ & - & - & - & - & - & - & - & - & 1.000 & $.979^{* *}$ & $.977^{* *}$ & $.971^{* *}$ & $.987^{* *}$ & $.961^{* *}$ & $.958^{* *}$ \\
\hline CL & - & - & - & - & - & - & - & - & - & 1.000 & $.981^{* *}$ & $.987^{* *}$ & $.988^{* *}$ & $.977^{* *}$ & $.979^{* *}$ \\
\hline SL & - & - & - & - & - & - & - & - & - & - & 1.000 & $.980^{* *}$ & $.985^{* *}$ & $.969^{* *}$ & $.977^{* *}$ \\
\hline POL & - & - & - & - & - & - & - & - & - & - & - & 1.000 & $.982^{* *}$ & $.983^{* *}$ & $.984^{* *}$ \\
\hline IOL & - & - & - & - & - & - & - & - & - & - & - & - & 1.000 & $.973^{* *}$ & $.975^{* *}$ \\
\hline ED & - & - & - & - & - & - & - & - & - & - & - & - & - & 1.000 & $.962^{* *}$ \\
\hline CPL & - & - & - & - & - & - & - & - & - & - & - & - & - & & 1.000 \\
\hline
\end{tabular}

N-618; ${ }^{* *}$ Significant at $\mathrm{p}<0.01$

scale. Such variations may be due to the environmental factors including temperature, salinity, oxygen, $\mathrm{pH}$, food availability and growth rate as being noticed in other species (Barlow, 1961; Lindsey, 1988). The range, mean, mode, median and standard deviation indicates a high degree of homogeneity within the population of $O$. pama occurring in Hooghly-Matlah Estuary of West Bengal, India.

\section{Acknowledgments}

The first author expresseses sincere gratitude to the Dean and Head, Department of Fisheries Resource Management, Faculty of Fishery Sciences, WBUAFS, Kolkata, West Bengal for the encouragement and support during the research works.

\section{References}

Barlow, G. W. 1961. Causes and significance of morphological variation in fishes. Syst. Zool., 10: 105-117.

Basu, S. P. 1975. Study on the biology of Otolithes argenteus. M. Sc. Thesis. Bombay University, Mumbai, India, 159 pp.

Bhakta, D., Das, S. K., Das, B. K., Nagesh, T. S. and Behera, S. 2019a. Food and feeding habits of Otolithoides pama (Hamilton, 1822) occurring from Hooghly-Matlah Estuary of West Bengal, India. Reg. Stud. Mar. Sci., 32: 100860.

Bhakta, D., Das, S. K., Das, B. K., Nagesh, T. S. and Samanta, R. 2020. Growth, mortality and exploitation status of Otolithoides pama (Hamilton, 1822) from Hooghly-Matlah estuary of West Bengal, India. Reg. Stud. Mar. Sci., 39: 101451. https://doi.org/10.1016/j.rsma.2020.101451.

Bhakta, D., Das, S. K., Das, B. K., Nagesh, T. S., Behera, S. and Das, S. C. S. 2019b. Length-weight relationship and condition factor of Otolithoides pama (Hamilton, 1822) from Hooghly-Matlah estuarine system of West Bengal, India. Indian J. Fish., 66(4): 51-59.

Bhuiyan, A. L. 1964. Fishes of Daccan. Asiatic Soc. Pakistan, Publ. No. 13, p. 105-106.

Bhuyan, S. K. 2003. Biology and stock assessment of some sciaenids off Paradeep Coast. Ph. D. Thesis. ICAR-Central Institute of Fisheries Education, Mumbai, India, 289 pp.

Cadrin, S. X. 2000. Advances in morphometric analysis of fish stock structure. Rev. Fish. Biol. Fish., 10: 91-112.

Chakraborty, S. K. 1988. Study on the sciaenids of Bombay waters. Ph. D. Thesis. Bombay University, Mumbai, India, $420 \mathrm{pp}$.

Chakraborty, S. K. 1992. Length-weight relationship and biometric study on three species of sciaenids from Bombay waters. J. Ind. Fish. Ass., 22: 41-48.

Dean, C. A., Rholf, F. J. and Dennis, E. S. 2003. Geometric morphometrics: Ten years of progress following the revolution. Ital. J. Zool., 71: 5-16. https://doi.org/10.1080/ 11250000409356545 .

Dobariyal, A. K., Kumar, K., Bisht, K. L., Bahuguna, P. K. and Joshi, H. K. 2006. Morphometric and meristic racial analysis of a hill stream fish Botia davi (Hora) from Garhwal Uttaranchal. Flora Fauna, 12(2): 213-221.

Dwivedi, S. N. and Menezes, M. R. 1974. A note on the morphometry and ecology of Brachirus orientalis (Bloch and Schneider) in the estuaries of Goa. Geobios, 1: 80-83.

FAO 1983. Species identification sheet for fishery purposes: Western Indian ocean. Food and Agricultural Organisation of the United Nations, Rome, Italy. 
Fischer, W. and Whitehead, P. J. P. 1974. FAO Species identification sheets for fishery purposes. Eastern Indian Ocean (Fishing Area 57) and Western Central Pacific (Fishing Area 71), vol. 14. Food and Agricultural Organisation of the United Nations, Rome, Italy.

Gandhi, V. 1982. Studies on the biometry and biology of Pennhia aneus (Bloch). Indian J. Fish., 29(1\&2): 79-84.

Grant, C. J. and Spain, A. V. 1977. Variation in the body shape of three species of Australian mullets (Pisces: Mugilidae) during the course of development. Aust. J. Mar. Freshw Res., 28: 723-738.

Haddon, V. and Willis, T. J. 1995. Morphometric and meristic comparison of orange roughy (Hoplostethus atlanticus: Trachichthyidae) from the Puysegur Bank and Lord Howe Rise, New Zealand and its implications for stock structure. Mar. Biol., 123(1): 19-27.

Heincke, F. 1898. Natural history of the herring, Part I, Dep. German Sea Fish Ver., Band 2, C XXXVI, 128 pp. (In German).

Ihssen, P. E., Booke, H. E., Casselman, J. M., McGlade, N., Payne, R. and Utter, F. M. 1981. Stock identification: materials and methods. Canad. J. Fish. Aquat. Sci., 38: 1838-1855.

Jayaprakash, A. A. 1974. Food and feeding habits of juvenile 'Koth' Otolithoides brunneus (Day) in Bombay waters. Indian J. Fish., 21(1): 127-140.

Jayasankar, P. 1989. Some observations on the biology of the blotched croaker Nibea maculata (Schneider, 1801) from Mandapam. Indian J. Fish., 36(4): 299-305.

Kumar, P., Chakraborty, S. K. and Jaiswar, A. K. 2012. Comparative otolith morphology of sciaenids occurring along the north-west coast of India. Indian J. Fish., 59(4): 19-27.

Kumar, T. 2012. Biology and stock assessment of Johnieops sina (Cuvier, 1830) from Ratnagiri waters. Ph. D. Thesis. ICAR-Central Institute of Fisheries Education (Deemed University), Mumbai, India, $185 \mathrm{pp}$.

Laevastu, T. 1965. Manual of methods in fisheries biology. Research on fish stocks. FAO Man. Fish. Sci., 4: 1-51.

Lindsey, C. C. 1988. Factors controlling meristic variation. Fish Physiol., 11B: 197-274.

Lowe-Mc Connell, R.H. 1971. Identification of freshwater fishes. In: Methods of assessment of fish production in freshwaters. Ricker, W.E. (Ed.), BlackWell. Scientific, Oxford and Edinburg, UK, p. 45-81.

Manojkumar, P. P. 2011. Fishery of sciaenids with some observations on the biology and stock assessment of Johnieops sina (Cuvier, 1830) exploited along the Malabar coast. J. Mar. Biol. Ass. India, 53(1): 68-74.
Manojkumar, P. P. and Acharya, P. 1990. Morphometry, lengthweight relationship and food and feeding habits of Otolithoides biauritus (Cantor, 1850) of Bombay waters. J. Indian Fish. Ass., 20: 31-36.

Mohan, R. S. L. 1991. A review of the sciaenid fishery resources of the Indian Ocean. J. Mar. Biol. Ass. India, 33(1\&2): 134-145.

Pillai, P. K. M. 1983. On biometry, food and feeding and spawning habits of Otolithes ruber (Schneider) from Porto Novo. Indian J. Fish., 30(1): 69-73.

Quilang, J. P., Basiao, Z. U., Pagulayan, R. C., Roderos, R. R. and Barrios, E. B. 2007. Meristic and morphometric variation in the silver perch, Leiopotherapon plumbeus (Kner, 1864), from three lakes in the Philippines. J. Appl. Ichthyol., 23:561-567.https://doi.org/10.1111/j.1439-0426. 2007.00862.x

Rahman, A. K. A. 2005. Freshwater fishes of Bangladesh. The Zoological Society of Bangladesh, Dhaka, Bangladesh, p. 328-329.

Raje, S. G. 1988. Occurrence of blackmouth croaker, Atrobucca nibe (Jordon and Thompson) off Veraval coast. Indian J. Fish., 35(4): 302-303.

Rao, V. K. 1963. Some aspects of the biology of 'Ghol' Pseudosciaena diacanthus (Lacepede). Indian J. Fish., 10(2): 413-459.

Sandhya, K. M., Chakraborty, S. K., Jaiswar, A. K., Kumar, J. T. and Mohite, S. 2015. Morphometry and length-weight relationship of Otolithes cuvieri (Trewavas, 1974) from Ratnagiri waters, Maharashtra, north-west coast of India. Indian J. Fish., 62(4): 99-103.

Shafi, M. and Quddus, M. M. A. 1982. Fisheries resources of Bangladesh. Bangla Academy, Dhaka, Bangladesh, p. 271-272 (In Bengali).

Silva, A. 2003. Morphometric variation among sardine (Sardina pilchardus) populations from the north-eastern Atlantic and the western Mediterranean. ICES J. Mar. Sci., 60: 1352-1360.

Snedecor, G. W. and Cochran, W. G. 1967. Statistical methods, $6^{\text {th }}$ edn. Oxford and IBH Publishing Co., New Delhi, $593 \mathrm{pp}$.

Talwar, P. K. 1995. Fauna of India and the adjacent countries, Pisces: Perciformes: Sciaenidae. In: A. K. Ghosh (Eds.), Zoological Survey of India, p. 144-145.

Talwar, P. K. and Jhingran, A. G. 1991. Inland fisheries of India and adjacent countries, vol. 2. Oxford and IBH Publishing, New Delhi, India.

Talwar, P. K. and Kacker, R. K. 1984. Commercial sea fishes of India. Zoological Survey of India, Kolkata, West Bengal, India, $997 \mathrm{pp}$. 
Telvekar, P. A. 2006. Biology and stock assessment of Johnieops sina (Cuvier 1830) from Mumbai waters. Ph. D. Thesis. ICAR-Central Institute of Fisheries Education, Mumbai, India.

Teugels, G. G. 1982. Preliminary results of a morphological study of five African species of the subgenus Clarias (Clarias) (Pisces; Clariidae). J. Nat. Hist., 16(3): 439-464. https://doi.org/10.1080/00222938200770351.
Turan, C. 2004. Stock identification of Mediterranean horse mackerel (Trachurus mediterraneus) using morphometric and meristic characters. ICES J. Mar. Sci., 61: 774-781. doi:10.1016/j.icesjms.2004.05.001.

Villaluz, A. C. and Maccrimmon, H. R. 1988. Meristic variations in milkfish Chanos chanos from Philippine waters. Mar. Biol., 97(1): 145-150. DOI: 10.1007/ BF00391254. 